\title{
DEVELOPMENT OF BANANA FINGERS USING PLANT GEL FROM NEO- LITSEA INVOLUCRATA
}

\author{
SB Navaratne \\ Department of Food Science and Technology, Faculty of Applied Sciences, University of Sri JayawardenaPu- \\ ra, Gangodawila, Nugegoda, Sri Lanka
}

Accepted: 27 September 2011

\begin{abstract}
Banana Fingers were prepared with matured unripe Ash banana or green banana (Musa acuminata) to be used as a supplement to potato fingers, a popular food. The soft kernel, of banana and its availability and relative cheapness make this product a viable substitute. About 120 banana fruits fingers, were peeled off, cut into 5*5*50mm rectangular pieces and dipped in an $800 \mathrm{ppm}$ Sodium meta bisulphite solution. The banana pieces were subjected separately to 8 treatment combinations in a two-factor factorial design with three variables at two levels: i.e. blanching process, chemical leavening and edible coating with Neolitsea involucrata (Davulkurudu DK or Kududavalu) leaf extract. The prepared banana fingers were divided into two portions and one portion was subjected for blanching process by dipping them in boiling water for 3 minutes. The rest portion was kept untreated. The blanched portion was divided into four portions in order to prepare 4 treatment combinations by dipping two of them in a sodium bicarbonate solution at $500 \mathrm{ppm}$ and the rest in pure water. Thereafter, two of them from each treatment were coated with viscous DK extract prepared by rubbing $3 \mathrm{~g}$ of blanched leaves in $50 \mathrm{ml}$ of water and the rest two were kept uncoated. Same procedure was adapted to the un blanched portion of banana fingers too. All eight treatments were replicated thrice and partially fried at $150^{\circ} \mathrm{C}$, stored in a freezer for $6 \mathrm{~h}$ in order to form ice crystals in the banana fingers. Finally, these eight treatments were fully fried at $180^{\circ} \mathrm{C}$ and subjected for measuring cooking time and organoleptic properties as against potato fingers. Results revealed that banana fingers possessed with best organoleptic properties in color, texture and over all acceptability as against potato fingers if they are treated with $D K$ extract and sodium bicarbonate and also revealed that banana fingers coated with DK extract having less rate of oil absorption (about 15-20\%) after frying as well as rapid cooking comparatively potato fingers.
\end{abstract}

Key words: Banana fingers, Neolitsea involucrata (Davulkurudu), Organoleptic properties, Edible coating

\section{INTRODUCTION}

Banana is a traditional fruit crop that has been diversified through out of the country as a result of its adaptability to the different climatic conditions (Illeperuma and Yayatunga 2001). The land extent under banana in Sri Lanka exceeds 50,000ha now. However, substantial amount of this crop is being wasted due to poor post harvest practices as market for this crop completely relies on ripen fruit, which is highly perishable under tropical environmental conditions (Anthony et al. 2004). Therefore, diversification of this fruit into other non-fruit food processing areas is an important aspect and a national duty (Ogheneova 2010). Since, Ash and Seeni kesel banana fruits contained substantial amount of less compact starch granules in the kernel (Dadzie 1998), there is a great potential to use these fruits into fast food industry. In spite of banana fruits having a vast scope for different types of food applications,

*Corresponding author : sbnava1234@yahoo.com technological know-how in this regard is a great barrier. Hence, it is worthwhile, in exploring possibilities of using raw banana fruit kernel in fast food industry by converting them into banana fingers while coating them with Neolitsea involucrata (Davulkurudu DK or Kududavalu) extract with the view to minimize oil absorption during frying. (Chandawat and Sen 2002)

Objectives of the study

Develop a supplementary product for potato fingers from unripe banana fruits having improved physical and organoleptic properties and reduced cooking time and absorption of oil during frying

\section{MATERIALS AND METHODS}

Preparation of Neolitsea involucrata leaf extract:

Fresh leaves obtained from $N$. involucrate plant were subjected for cooling with dehumidifying 
drying process for $18 \mathrm{~h}$ and $3 \mathrm{~g}$ of dried leaves were blanched for 3 minutes and washed with cold water in order to remove volatile substances of the leaf extract. A thick gel was prepared with $2 \mathrm{~g}$ of blanched leaves after rubbing and agitating with $50 \mathrm{ml}$ of cold water.

\section{Preparation of treatments}

Two-factor factorial design with three variables at two levels were used to prepare banana finger samples. These three variables were heat treated (blanching process), chemical treatment (introduction of leavening agent-Sodium bicarbonate) and coating with Davulkurudu (DK) leaf extract. Hundred and twenty fully matured Ash or green banana were taken; peel peeled off, cut into rectangular shape fingers $(5 * 5 * 50 \mathrm{~mm})$ and dipped them in an 800ppm sodium metabisulphite solution (SMS). The raw banana fingers were taken out of the SMS solution and divided into two portions and one portion was subjected for blanching process by immersing them in hot boiling water for 3 minutes. The rest portion was kept untreated. These two portions were divided into two equal portions again and one portion of each was dipped in 500ppm sodium bicarbonate solution for 5minutes. The rest two portions were dipped in pure water. Four portions obtained from these treatments were divided into two equal potions again and one portion of each treatment was dipped in thick and viscous DK extract for 3 minutes. The rest four portions were kept without dipping in DK extract. All eight treatments were partially fried in vegetable oil at $150^{\circ} \mathrm{C}$, treated with $800 \mathrm{ppm}$ vitamin $\mathrm{E}(\alpha$ tocopherol) until surface of the pieces converted into scant golden color. Thereafter, they were packed in low density polythene pouches and stored in a freezer for $6 \mathrm{~h}$ in order to form ice crystals. Thereafter, all treatments were deep fried and evaluated for cooking quality, (Cooking time), rate of oil absorption, and organoleptic properties such as color, taste, texture, aroma and over all acceptability. Results, obtained from the study were compared with the same property of fried potato fingers, were analyzed using non parametric (KruskallWallies) as well as parametric ANOVA. All treatments were replicated thrice.

\section{Cooking time}

Frozen banana fingers were fired in hot oil at $180^{\circ} \mathrm{C}$ until completion of the cooking process.
In measuring cooking time, a piece of banana finger was taken from the frying pan periodically and placed it in between two slides of glass, and crushed it. If cooking process is not completed an uncooked portion (white belly) is left over, which is visible as a white ungelatinized starch patch.

\section{Organoleptic properties}

Organoleptic properties of banana fingers were evaluated by fifteen-member trained sensory panel. Respondents were asked to indicate their choice by a numerical number in between 1 to 9 over a nine point hedonic scale.

\section{Sensory profiles of the best treatment}

Mean score value, secured by the each sensory stimulus of best treatments during the sensory evaluation were used to draw sensory profiles; because these profiles are capable to demonstrate the superior treatments among the treatment combinations.

\section{RESULTS AND DISCUSSION}

\section{Cooking time}

Mean cooking time of three replicates of eight treatments was measured and results are given in the table 1.

The data given in the table 02 analyzed statistically using parametric ANOVA and results revealed that there is no significant

different between the cooking time of all treatments, because calculated $\mathrm{F}$ value $(0.78)$ is lower than the table $\mathrm{F}_{18}^{8}, 5 \%$ value (2.51). Therefore, thereafter, mean variations of each treatment was calculated in order to determine the best treatment. The results clearly indicate that the best treatment is $\mathrm{BB}+\mathrm{NaHCO}_{3}+\mathrm{LE}$ as it takes least cooking time comparatively other

Table 1: Treatment combination used to prepare banana fingers and their cooking time (in sec)

\begin{tabular}{|c|c|c|}
\hline Treatment combination & $\begin{array}{l}\text { Cooking } \\
\text { time }(\mathrm{Sec})\end{array}$ & $\mathrm{X} \pm \mathrm{SD}$ \\
\hline $\mathrm{RB}$ & 105 & $105 \pm 5.7$ \\
\hline $\mathrm{BB}$ & 105 & $105 \pm 5.7$ \\
\hline $\mathrm{RB}+\mathrm{NaHCO}_{3}$ & 90 & $90 \pm 3.99$ \\
\hline $\mathrm{BB}+\mathrm{NaHCO}_{3}$ & 80 & $80 \pm 4.02$ \\
\hline $\mathrm{RB}+\mathrm{LE}$ & 105 & $105 \pm 5.7$ \\
\hline $\mathrm{BB}+\mathrm{LE}$ & 105 & $105 \pm 5.7$ \\
\hline $\mathrm{RB}+\mathrm{NaHCO}_{3}+\mathrm{LE}$ & 90 & $90 \pm 4.7$ \\
\hline $\mathrm{BB}+\mathrm{NaHCO}_{3}+\mathrm{LE}$ & 80 & $80 \pm 2.2$ \\
\hline Potato fingers & 95 & $95 \pm 3.2$ \\
\hline
\end{tabular}

$\mathrm{RB}=$ Raw banana, $\mathrm{BB}=$ Blanched banana, $\mathrm{LE}=\mathrm{Leaf}$ extract 
treatments. Therefore, sodium bicarbonate has a big influence in accelerating of cooking time of banana fingers. Reason for this rapid cooking process is sudden liberation of $\mathrm{CO} 2$ gas, when banana fingers are immersed in very hot oil (Swaminathan 1988). The ice crystals still present in the frozen banana fingers also contribute for rapid cooking process by converting them into steam with a high pressure due to high temperature available in the frying pan. Blanching process also somewhat contribute for rapid cooking process (Bomben et al 1975) as blanching process would facilitate to absorb more $\mathrm{NaHCO}_{3}$ into the membranes of banana fingers (Scott 1981). Because, heat treatment is capable to converts the hard cell structure of banana into a soft and permeable state. When comparing cooking time with the potato fingers, the best treatment out of all is blanched banana fingers treated with $\mathrm{NaHCO}_{3}$ along with the $D K$ extract.

\section{Organoleptic properties}

Organoleptic properties of banana fingers such as color, taste, smell, mouth feel and over all acceptability were evaluated by sensory mean, using a fifteen-member trained sensory panel and results were analyzed using KruskalWallies non parametric ANOVA.

\section{Color}

Color is a visual sense, perceptual sensitivity of which is directly related to the consumer preference and palatability. Therefore, responses for this sensory stimulus for banana fingers were analyzed statistically and results are given in the table 2

The statistical analysis clearly indicates that best treatments out of all were $a_{1} b_{1} c_{1}$ and $a_{1} b_{0} c_{1}$ comparatively color of potato fingers. Hence, heat treatment and $D K$ leaf extract having a big influence in maintaining color of the banana fingers. Reason for this phenomenon is enzymatic browning reaction, which is further being induced by the ambient oxygen (Norman and James 1977), when product is exposed to the normal atmosphere. Even though the blanching process inactivates the most of enzymes presence in the outer periphery of banana fruit, some enzymes in the inner may be still active and capable to keep on browning reaction with atmospheric oxygen (Swaminathan 1988). When the banana fingers were enveloped with
Table 2 Mean variation of different treatment on sensory stimulus-color

\begin{tabular}{|c|c|c|c|}
\hline Treatment & $\begin{array}{l}\text { Rank } \\
\text { mean }\end{array}$ & $\begin{array}{l}\text { Mean } \\
\text { difference }\end{array}$ & Significance \\
\hline $\mathrm{RB}+\mathrm{LE}$ & 39.3 & $58.0>45.6$ & * \\
\hline $\mathrm{RB}$ & 45.7 & $51.6>45.6$ & $*$ \\
\hline $\mathrm{RB}+\mathrm{NaHCO}_{3}$ & 48.2 & $49.1>45.6$ & $*$ \\
\hline BB & 49.1 & $48.2>45.6$ & $*$ \\
\hline $\mathrm{BB}+\mathrm{NaHCO}_{3}$ & 50.0 & $47.3>45.6$ & $*$ \\
\hline $\mathrm{RB}+\mathrm{NaHCO}_{3}+\mathrm{LE}$ & 51.4 & $45.9>45.6$ & $*$ \\
\hline $\mathrm{BB}+\mathrm{LE}$ & 96.1 & $1.2<45.6$ & NS \\
\hline potato & 97.0 & $0.3<45.6$ & NS \\
\hline $\mathrm{BB}+\mathrm{NaHCO}_{3}+\mathrm{LE}$ & 97.3 & & \\
\hline
\end{tabular}

Mean separation of the treatments $=45.6, *$ significant, $\mathrm{NS}=$ Not significant $\mathrm{RB}=$ Raw banana, $\mathrm{BB}=$ Blanched banana, $\mathrm{LE}=$ Leaf extract

a mucilaginous layer from $D K$ leaf extract, which prevents the product being exposed to the normal atmosphere, as this mucilaginous layer act as an oxygen barrier. Hence, the treatments having without coated a mucilaginous layer, susceptible for enzymatic browning reaction (Maccrice et al. 2004). Therefore, DK extract is quite capable to control browning reaction. Thus, the color consistency of the treatments $\mathrm{BB}+\mathrm{NaHCO}_{3}+\mathrm{LE}$ and $\mathrm{BB}+\mathrm{LE}$ are almost compatible with the color of potato fingers.

\section{Taste}

Taste is a gustatory sense, perceptual sensitivity of which persuades the consumer to try out or refrain the product. The banana fingers made out of eight treatment combinations were evaluated in respect to the sensory stimulus taste and statistically analyzed results in this regard are given in the table 3 .

There is no significant different between the treatments for taste including the potato fingers (Table $3)$. Reason for this phenomenon is breaking down of the mucilaginous structure of DK extract, which merely comprised more water (About 98-99\%) and lesser amount of other constituents, preferably polysaccharides, when frying process is carried out. Water and polysaccharides are tasteless substances in the DK extract and most of other unpleasant constituents in the $D K$ leaf are being evaded when blanching process is carried out (Wealth of India 1991). In Addition, trace amount of volatile substances are being evaporated again when banana fingers are subjected for deep frying process. Therefore fried banana fingers from different treatment combinations do not impart any taste difference. Whereas, Sodium bicarbonate is also breaking down into $\mathrm{CO} 2$ and 
Table 3 Mean variation of different treatment on sensory stimulus-Taste

\begin{tabular}{|c|c|c|c|}
\hline Treatment & $\begin{array}{l}\text { Rank } \\
\text { mean }\end{array}$ & $\begin{array}{l}\text { Mean } \\
\text { difference }\end{array}$ & Significance \\
\hline $\mathrm{RB}+\mathrm{LE}$ & 52.0 & $45.3<45.6$ & NS \\
\hline $\mathrm{RB}$ & 53.1 & $44.2<45.6$ & NS \\
\hline $\mathrm{RB}+\mathrm{NaHCO}_{3}$ & 54.6 & $42.7<45.6$ & NS \\
\hline BB & 55.6 & $41.7<45.6$ & NS \\
\hline $\mathrm{BB}+\mathrm{NaHCO}_{3}$ & 59.8 & $37.5<45.6$ & NS \\
\hline $\mathrm{RB}+\mathrm{NaHCO}_{3}+\mathrm{LE}$ & 82.1 & $25.2<45.6$ & NS \\
\hline $\mathrm{BB}+\mathrm{LE}$ & 90.2 & $<45.6$ & NS \\
\hline potato & 90.3 & $<45.6$ & NS \\
\hline $\mathrm{BB}+\mathrm{NaHCO}_{3}+\mathrm{LE}$ & 97.3 & & NS \\
\hline
\end{tabular}

Mean separation of the treatments $=45$.

$\mathrm{Na}_{2} \mathrm{CO} 3$ during the frying process and low concentration of $\mathrm{NaHCO}_{3}$ does not impart an adverse effect on to the flavor profile of the product (Fellow 1988).

\section{Aroma}

Smell is also a very important sensory characteristic as influence of which interact or distract the consumer from the food. Hence, results pertaining to this sensory stimulus for banana fingers are given in the table 4.

There was no significant difference between treatments along with the potato fingers as mean separation was greater than the mean differences of the treatments (Table 4). Reason for this phenomenon was that $D K$ extract and $\mathrm{Na}-$ $\mathrm{HCO}_{3}$ treatments were incapable to disturb odor profile of the product. Because, DK extract and $\mathrm{NaHCO}_{3}$ are disintegrated into water, $\mathrm{CO} 2$ and other volatile substances during frying, as described in the sensory stimulus.

\section{Mouth feel}

Mouth feel is a gustatory sense that derived from a product when it is being subjected to a chewing process. The statistically analyzed results pertaining to the mouth feel of banana fingers are given in the table 5 . The statistically

Table 4 Mean variation of different treatment on sensory stimulus-Smell

\begin{tabular}{lllll}
\hline Treatment & $\begin{array}{l}\text { Rank } \\
\text { mean }\end{array}$ & \multicolumn{2}{l}{$\begin{array}{l}\text { Mean } \\
\text { difference }\end{array}$} & Significance \\
\hline Potato & 50.6 & 44.9 & $<45.6$ & NS \\
RB+ NaHCO & 53.9 & 41.6 & $<45.6$ & NS \\
$\mathrm{RB}+\mathrm{LE}$ & 57.0 & $38.5<45.6$ & $\mathrm{NS}$ \\
$\mathrm{BB}$ & 59.2 & $36.3<45.6$ & $\mathrm{NS}$ \\
$\mathrm{BB}+\mathrm{LE}$ & 65.1 & $30.4<45.6$ & $\mathrm{NS}$ \\
$\mathrm{RB}+\mathrm{NaHCO}_{3}+\mathrm{LE}$ & 67.0 & $28.5<45.6$ & $\mathrm{NS}$ \\
$\mathrm{BB}+\mathrm{NaHCO}_{3}$ & 68.5 & $27.0<45.6$ & $\mathrm{NS}$ \\
$\mathrm{RB}$ & 95.5 & $00<45.6$ & $\mathrm{NS}$
\end{tabular}

$\mathrm{BB}+\mathrm{NaHCO}_{3}+\mathrm{LE} \quad 95.5$

Mean separation of the treatments $=45.6 \quad$ NS=Not Significant analyzed results clearly indicate that best treatments out of all were $\mathrm{BB}+\mathrm{NaHCO}_{3}+\mathrm{LE}$ and $\mathrm{BB}+\mathrm{LE}$ comparatively potato fingers (Table 5 ). Reasons for better mouth feel of these two treatments are soft and bit crunch nature of the banana fingers as against potato fingers. Because, these two treatments contained sodium bicarbonate, a leavening agent, which liberate CO2 (Swaminathan 1988), when product is

Table 5 Mean variation of different treatment on sensory stimulus-Mouth feel

\begin{tabular}{|c|c|c|c|c|}
\hline Treatment & $\begin{array}{l}\text { Rank } \\
\text { mean }\end{array}$ & $\begin{array}{l}\text { Mean } \\
\text { differ }\end{array}$ & ence & Significance \\
\hline$\overline{\mathrm{RB}}$ & 16.5 & 94.6 & $>45.6$ & * \\
\hline $\mathrm{RB}+\mathrm{LE}$ & 27.5 & 83.6 & $>45.6$ & $*$ \\
\hline $\mathrm{BB}$ & 53.6 & 57.5 & $>45.6$ & $*$ \\
\hline $\mathrm{BB}+\mathrm{NaHCO}_{3}$ & 53.6 & 57.6 & $>45.6$ & $*$ \\
\hline $\mathrm{RB}+\mathrm{NaHCO}_{3}+\mathrm{LE}$ & 61.6 & 49.5 & $>45.6$ & $*$ \\
\hline $\mathrm{RB}+\mathrm{NaHCO}_{3}$ & 64.6 & 46.5 & $>45.6$ & $*$ \\
\hline $\mathrm{BB}+\mathrm{LE}$ & 100.7 & 10.4 & $<45.6$ & NS \\
\hline Potato 1 & 102.3 & 8.8 & $<45.6$ & NS \\
\hline \multicolumn{5}{|c|}{$\mathrm{BB}+\mathrm{NaHCO}_{3}+\mathrm{LE} 111.1$} \\
\hline
\end{tabular}

Mean separation of the treatments $=45.6 *$ significant $\mathrm{NS}=$ Not Significant $\mathrm{RB}=\mathrm{Raw}$ banana, $\mathrm{BB}=$ Blanched banana, $\mathrm{LE}=$ Leaf extract

immersed in hot oil $\left(180^{\circ}-220^{\circ} \mathrm{C}\right)$ from the inner part of the banana fingers and convert them into a porous nature. On the other hand, as these two treatments have been coated with DK extract, the coated gel itself is converted into a microfilm; when product is being subjected for partially frying process, before refrigeration. The formed microfilm can act as a barrier during the final cooking process by exerting somewhat resistant to the steam. Therefore, liberated steam being pressurized in banana finger itself into some extent, that results cooking is taking place at a slightly higher temperature than the banana fingers did not coat with DK. extract. Hence, banana fingers fried at somewhat higher temperature result to have a soft texture, because cooking at a higher temperature renders a tender product (Norman and James 1977). Therefore, due to combined effect of these two factors DK extract and sodium bicarbonate, banana fingers impart a better mouth feel, when product is being chewed in the mouth. Hence, the mouth feel of banana fingers prepared out of treatments $\mathrm{BB}+\mathrm{NaHCO}_{3}+\mathrm{LE}$ and $\mathrm{BB}+\mathrm{LE}$ are better than the mouth feel of potato fingers.

\section{Over all acceptability}

Over all acceptability of a product is a cumulative response for the whole sensory stimuli per- 
ceived by the consumer towards a product. Hence response of the respondents pertaining to the banana fingers in this regard were evaluated statistically and results are given in the table 6

The statistically analyze results given in the table 6 clearly indicates that best treatments for over all acceptability comparatively potato fingers are $\mathrm{BB}+\mathrm{NaHCO}_{3}+\mathrm{LE}$ and $\mathrm{BB}+\mathrm{LE}$. Reasons for this phenomenon was combined influence of the three sensory stimuli color, mouth feel and over all acceptability as these three organoleptic properties were dominated in the treatments of $\mathrm{BB}+\mathrm{NaHCO}_{3}+\mathrm{LE}$ and $\mathrm{BB}+\mathrm{LE}$. To further, elaborate over all acceptability of these two treatments, sensory profiles were drawn along with the potato fingers, which are given in the figure 1.

Table 6 Mean variation of different treatment on sensory stimuli- overall acceptability

\begin{tabular}{lllll}
\hline Treatment & $\begin{array}{l}\text { Rank } \\
\text { mean }\end{array}$ & $\begin{array}{l}\text { Mean difference Significance } \\
\text { as against mean } \\
\text { separation }\end{array}$ \\
\hline $\mathrm{RB}+\mathrm{LE}$ & 25.7 & 86.4 & $>45.6$ & $*$ \\
$\mathrm{BB}$ & 34.9 & 77.2 & $>45.6$ & $*$ \\
$\mathrm{RB}$ & 42.9 & 69.2 & $>45.6$ & $*$ \\
$\mathrm{BB}+\mathrm{NaHCO}_{3}+\mathrm{LE}$ & 52.2 & 60.1 & $>45.6$ & $*$ \\
$\mathrm{RB}+\mathrm{NaHCO}_{3}$ & 63.3 & 48.8 & $>45.6$ & $*$ \\
$\mathrm{RB}+\mathrm{NaHCO}_{3}+\mathrm{LE}$ & 65.5 & 46.6 & $>45.6$ & $*$ \\
$\mathrm{BB}+\mathrm{LE}$ & 99.8 & 12.3 & $<45.6$ & $\mathrm{NS}$ \\
$\mathrm{BB}+\mathrm{NaHCO}$ & 112.1 & 00 & $<45.6$ & $\mathrm{NS}$ \\
potato & 112.1 & & \\
\hline
\end{tabular}

Mean separation of the treatments $=45.6 *$ significant $\mathrm{NS}=$ Not Significant $\mathrm{RB}=$ Raw banana, $\mathrm{BB}=\mathrm{Blanched}$ banana, $\mathrm{LE}=\mathrm{DK}$ Leaf extract

Sensory profiles depicted in the Fig 1 also indicate that best sensory profile is cited by the treatment $\mathrm{BB}+\mathrm{NaHCO}_{3}+\mathrm{LE}$ (Blanched and treated with $\mathrm{NaHCO}_{3} \& \mathrm{DK}$ ) as against potato fingers.

\section{Rate of oil absorption of the best treatment against potato fingers}

Oil absorption rate of best treatment with and without $D K$ leaf extract was determined along with the Potato fingers and results given in the table 7

The data given in the table indicate that $D K$ leaf extracts is capable to minimize oil absorption during the process of frying. Reason for this phenomenon is the gum layer, which envelop the banana fingers and makes a thin micro film when banana fingers were subjected to deep frying process. The formed thin film re-

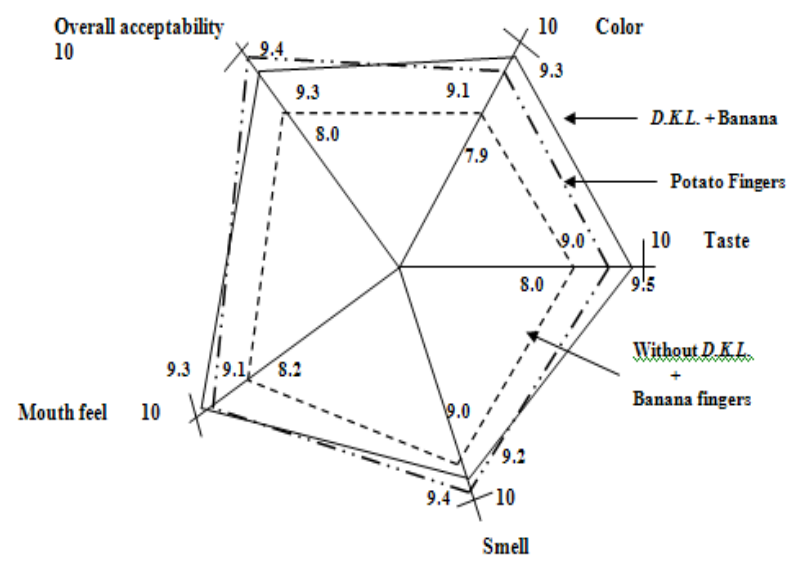

Fig 1 sensory profile of $\mathrm{BB}+\mathrm{NaHCO}_{3}+\mathrm{LE}$, $\mathrm{RB}+\mathrm{NaHCO}_{3}+\mathrm{LE}$ and potato fingers

sists to oil ingress into the product. Therefore, coating of banana fingers with $D K$ leaf extract is a viable option for the fast food industry in minimizing of oil absorption during the frying process. Meanwhile, gum of the $D K$ leaf extract is capable to reduce oil absorption by 25 -

Table 7 Rate of oil absorption of banana fingers coated with and without DK extract as against potato fingers

\begin{tabular}{lcc}
\hline \multirow{2}{*}{$\begin{array}{l}\text { Rate of oil absorption (Mean value of } 6 \text { replicates) } \\
\text { and } \mathrm{X} \pm \text { SD value }\end{array}$} \\
\hline Potato fingers & \multicolumn{2}{c}{ Banana fingers } \\
\cline { 2 - 3 } & $\begin{array}{l}\text { Without DK } \\
\text { extract }\end{array}$ & $\begin{array}{l}\text { With DK } \\
\text { extract }\end{array}$ \\
\hline $20.1 \pm 0.33$ & $18.6 \pm 0.32$ & $13.2 \pm 0.10$
\end{tabular}

$30 \%$ compared with banana fingers, coated with no DK extract.

\section{CONCLUSION}

Banana fingers can be prepared by using fully matured Ash banana or green banana. The fruits are to be peel off, cut into fingers $(5 * 5 * 50 \mathrm{~mm})$ and dipped in sodium metabisulphite solution (800ppm). Thereafter these fingers shall be blanched by dipping them in boiling water for 3 minutes. Blanched banana fingers are to be dipped in cold water, mixed with $\mathrm{NaHCO} 3$ (500ppm) for 5 minutes and to be coated with Neolitsea involucrata (Davulkurudu) leaf extract by dipping them in the gel for 5 minutes. Banana fingers coated with $D K$ leaf extract should be partially fried until surface becomes scant golden color in vegetable oil treated with vitamin $\mathrm{E}$ ( $\alpha$ tocopherol) at $150^{\circ} \mathrm{C}$. Partially fried banana fingers are to be frozen until formation of ice crystals. 
Well frozen banana fingers are ready to cook now.

\section{REFERENCES}

Ogheneova S 2010 African Journal of Bio technology Vol. 9(54) pp 9135-9141, 29 December, ISSN 1684 - 5315, 2010 Academic Jounal

Anthony S, Abeywickrama R, Dayananda R, Wilson S and Arambewela L 2004, fungal pathogens associated with Banana fruits in Sri Lanka, Department of Botany, University of Kelaniya, Sri Lanka

Bomben JC, Dietrich WC, Hudson JS, Hamilton HK 1975 Yield and solid loss in steam blanching, cooling and freezing vegetables J. Food Sci. 40:660-64

Chandrawat BS and Sen NL 2002 Principles of fruit culture, Agrotech publishing academy pp185 $-193$.

Dadzie BK 1988 Postharvest characteristics of black banana, cooking banana and plantain hybrids - International plant genetic resources Institute Maccarese, Fiumicino, Rome, Italy

Fellow P 1988 Food processing technology principles and practices Horwood E, Govwraamma RV and Mahhadeviah M 1996, Food packaging materials, New Delhi, Tata McGraw - Hill Public Company Limited

Illeperuma CK and Yayatunge KGRL 2001 Osmo air dehydration of Kolikuttu banana Journals of National Science Foundation Sri Lanka pp1-57.

Norman W Desrosier and James N Desrosier 1977 The technology of food preservation, fourth edition, CBS Publishing and distributers 485, Jain Bhawan, BholeNath Nagar, Shahara, Delhi 110032 - India

Scott EP 1981 Energy consumption in steam blanches J. Food processing II:577-588.

Swaminathan M 1988 Hand book of food science and experimental foods, The Bangalore printing and publishing co. Ltd 96-97.

Mccurice R, Marshall, Jeongmok Kim and Cheng-I Wei-Enzymatic Browning, www.fao.org/ag/ags/ agsi/ENZYMEFINAL/Enzymatic\%20 Browning.html.

Wealth of India - A dictionary of Indian raw materials and industrial products, council of scientific research and industrial research, National institute of science communication and information resources, 